\title{
Effects of adding a mixture of malate and yeast culture (Saccharomyces cerevisiae) on milk production of Murciano-Granadina dairy goats
}

\author{
Ahmed A.K. SALAMA ${ }^{\mathrm{a}, \mathrm{b}}$, Gerardo CAJA ${ }^{\mathrm{a} *}$, Daniel GARíN ${ }^{\mathrm{a}}$, \\ Elena Albanella ${ }^{\mathrm{a}}$, Xavier Such ${ }^{\mathrm{a}}$, Ramón CASAls ${ }^{\mathrm{a}}$ \\ a Producció Animal, Departament de Ciència Animal i dels Aliments, \\ Universitat Autònoma de Barcelona, 08193 Bellaterra, Spain \\ b Sheep and Goat Research Department, Animal Production Research Institute, \\ 4 Nadi El-Said St., 12311 Dokki, Giza, Egypt
}

(Received 16 October 2001; accepted 31 July 2002)

\begin{abstract}
Twenty-four Murciano-Granadina dairy goats were used to investigate the effects of supplementation with a mixture of malate and yeast (Saccharomyces cerevisiae) on milk production. The goats were machine milked once a day after parturition and were assigned to two balanced groups on week 4 of lactation. The experimental groups were kept separately in pens and were fed a daily diet based on a dehydrated forage mixture (alfalfa hay: maize whole plant, $1: 1$ ) ad libitum, $0.3 \mathrm{~kg}$ alfalfa pellets and $0.2 \mathrm{~kg}$ barley grain. The basal diet was completed with $0.6 \mathrm{~kg}$ concentrate pellets fed individually. Two different dietary treatments were randomly assigned to each goat group: control (without supplementation) and supplemented (with a mixture of malate and yeast included in the concentrate at a level of $10 \mathrm{~g} \cdot \mathrm{kg}^{-1}$ ). Feed intake, milk yield, milk composition and body weight were evaluated from week 4 to 16 of lactation. Malate content of the control and supplemented concentrate was 2.4 and $6.0 \mathrm{~g} \cdot \mathrm{kg}^{-1} \mathrm{DM}$, respectively. Supplementation with the malate and yeast culture mixture did not affect $(P>0.05)$ feed intake (2.04 vs. $\left.2.03 \mathrm{~kg} \mathrm{DM} \cdot \mathrm{d}^{-1}\right)$, milk yield $\left(2.09 \mathrm{vs.} 2.08 \mathrm{~L} \cdot \mathrm{d}^{-1}\right)$, milk fat (5.17 vs. $4.85 \%)$, milk protein $(3.70$ vs. $3.63 \%)$ or milk casein $(2.57$ vs. $2.51 \%)$ for the control vs. the supplemented goats, respectively. Nevertheless, the supplemented goats gained more body weight than the control goats ( $39 \mathrm{vs} .19 \mathrm{~g} \cdot \mathrm{d}^{-1} ; P<0.05$ ). We conclude that supplementation with the mixture of malate and yeast culture, under the conditions of our experiment, had no beneficial effects on the performance of dairy goats. The relatively high contents of malic acid in the forage mixture $\left(7.3 \mathrm{~g} \cdot \mathrm{kg}^{-1} \mathrm{DM}\right)$ and in the alfalfa pellets $\left(14.2 \mathrm{~g} \cdot \mathrm{kg}^{-1} \mathrm{DM}\right)$ may have decreased the response to malate in the supplemented diet.
\end{abstract}

malic acid / yeast / milk production / dairy goats / alfalfa

*Correspondence and reprints

Tel.: 3493581 1442; fax: 3493581 1494; e-mail: gerardo.caja@uab.es 
Résumé - Effet de l'addition d'un mélange de malate et de levure (Saccharomyces cerevisiae) sur la production laitière chez la chèvre Murciano-Granadina. Vingt-quatre chèvres laitières Murciano-Granadina ont été utilisées pour étudier les effets de la supplémentation d'un mélange de malate et de levure (Saccharomyces cerevisiae) sur la production du lait. Les chèvres étaient traites à la machine, une fois par jour, dès la mise bas et ont été réparties dans deux groupes équilibrés à partir de la quatrième semaine de lactation. Les lots expérimentaux ont été logés séparément et la ration de base journalière était constituée d'un mélange de fourrages déshydratés (foin de luzerne:maïs plante entière, 1:1) distribué ad libitum, $0,3 \mathrm{~kg}$ de pellets de foin de luzerne déshydratée et $0,2 \mathrm{~kg}$ d'orge en grain. La ration de base a été enrichie par $0,6 \mathrm{~kg}$ de concentré d'une façon individuelle. Deux traitements différents ont été appliqués aléatoirement à chaque groupe de chèvres : régime témoin (sans supplément) et régime supplémenté (avec mélange de malate et de levure inclus dans le concentré à un niveau de $10 \mathrm{~g} \cdot \mathrm{kg}^{-1}$ ). L'ingestion, la production de lait, la composition du lait et le poids vif ont été évalués de la $4^{\mathrm{e}}$ à la $16^{\mathrm{e}}$ semaine de lactation. Les concentrations en malate dans le concentré témoin et supplémenté étaient de 2,4 et de $6,0 \mathrm{~g} \cdot \mathrm{kg}^{-1} \mathrm{MS}$, respectivement. La supplémentation en malate et en levure n'a pas affecté $(P>0,05)$ l'ingestion $\left(2,04\right.$ contre $\left.2,02 \mathrm{~kg} \mathrm{MS} \cdot \mathrm{j}^{-1}\right)$, la production de lait $(2,09$ contre $\left.2,08 \mathrm{~L} \cdot \mathrm{j}^{-1}\right)$, ni les teneurs du lait en matière grasse $(5,17$ contre $4,85 \%)$, en matière protéique ( 3,70 contre $3,63 \%)$, et en caséine ( 2,57 contre $2,51 \%)$ lorsque l'on compare le régime témoin au régime supplémenté, respectivement. Cependant, le gain moyen quotidien a été plus élevé chez les chèvres du groupe supplémenté que celles du groupe témoin (39 contre $\left.19 \mathrm{~g} \cdot \mathrm{j}^{-1} ; P<0,05\right)$. Nous concluons que la supplémentation en malate et en levure, dans les conditions de notre expérience, n'a pas eu d'effets bénéfiques sur les performances des chèvres laitières. Les concentrations relativement élevées en malate dans le mélange de fourrages $\left(7,3 \mathrm{~g} \cdot \mathrm{kg}^{-1} \mathrm{MS}\right)$ et dans les pellets de luzerne $\left(14,2 \mathrm{~g} \cdot \mathrm{kg}^{-1} \mathrm{MS}\right)$ ont pu limiter la réponse à la supplémentation de l'aliment avec le malate.

acide malique / levure / production de lait / chèvre / luzerne

\section{INTRODUCTION}

The increasing concern regarding the use of antibiotics in animal feeding has led to the recent banning of a wide range of additives. Organic acids and probiotics may provide an alternative to antibiotics and may be introduced as feed additives for ruminants $[4,10]$. Certain anions of $\mathrm{C}_{4}$ dicarboxylic acids, such as malate and fumarate, are key metabolites in the citric acid cycle of ruminal bacteria, reducing the production of methane and increasing the production of propionate and dry matter digestibility $[2,8]$.

High amounts of fermentable carbohydrates in the diet are associated with high lactate production which causes acidosis and reduces feed efficiency in ruminants. Lactate can be fermented in the rumen by Selenomonas ruminantium, which accounts for more than $50 \%$ of the total viable bacteria within the rumen [7], to form pro- pionate. Malate stimulates lactate uptake by $S$. ruminantium [18] and thus improves the rumen environment and increases propionate production.

Malate is found naturally in common forages fed to ruminants in variable concentrations [6]. The content of malate is greater in leaves than in stems, in legumes than in grasses, and in young than in mature forages. Also, fresh forages contain higher malate than hay due to soluble nutrient losses during haymaking [6]. Malate content in ruminant diets can be increased naturally by the inclusion of forages rich in malate and forages improved by plant breeding techniques for high malate concentration or artificially by the addition of industrially synthesized malate [10]. The results of the few experiments conducted on malate supplementation in dairy cows $[14,24]$ are contradictory. Considerable research is needed on the use of malate as a strategy for increasing rumen efficiency 
and reducing methane emissions, as indicated by the European Commission [10].

Yeast cultures, mainly Saccharomyces cerevisiae, may also improve ruminal fermentation $[5,17]$ and therefore provide another alternative to antimicrobial compounds. However, the results on the use of $S$. cerevisiae in dairy cows $[9,20,23]$ and dairy goats $[11,13]$ are also contradictory. Dietary factors such as forage concentrate ratio and forage type are important in determining the response to malate and yeast culture supplementation [20], which may explain the contradiction found in the results of the previous studies.

Nisbet and Martin [18] reported that $S$. cerevisiae contains significant concentrations of L-malate and observed that similar concentrations of L-malate alone multiplied lactate uptake by approximately three. Moreover, positive results of the addition of a malate and yeast mixture to the concentrate of intensively fattened lambs have been reported [4].

To our knowledge no studies on the supplementation of malate alone or mixed with yeast have been conducted in dairy goats. Therefore, the objective of this study was to evaluate the response to the supplementation of a mixture of malate and yeast on lactation performances of dairy goats fed diets based on processed alfalfa, as is usual in the Mediterranean area.

\section{MATERIALS AND METHODS}

\subsection{Animals and management conditions}

Twenty-four Murciano-Granadina goats (3 primiparous and 21 multiparous; $4.0 \pm$ 0.2 years in average) from the herd of the S1GCE (Servei de Granges i Camps Experimentals) of the Universitat Autonoma of Barcelona were used in a lactation trial from week 4 to 16 of lactation. The kids (1.92 \pm 0.12 per goat) were separated from their mothers within the first $8 \mathrm{~h}$ after birth, and then were reared artificially with milk substitutes. The goats were milked once daily $(9.00 \mathrm{~h})$ in a double-12 stall parallel milking parlor (Westfalia Landtechnik, Granollers, Spain) with recording jars and down milk pipeline. Milking was conducted at a vacuum pressure of $42 \mathrm{kPa}$, a pulsation rate of $90 \mathrm{pulses} / \mathrm{min}$, and a pulsation ratio of $66 \%$. The milking routine included machine milking with machine stripping before the cluster removal and teat dipping [19].

Goats were divided into two groups at week 4 of lactation according to parity and to milk yield and body weight (BW) recorded at weeks 2 and 3. During the experiment, each group was kept in a separate pen. The daily ration per goat was offered in the pen once daily after milking and consisted of a basal diet of a dehydrated forage mixture (1:1) of alfalfa hay and maize whole plant offered ad libitum, $0.3 \mathrm{~kg}$ alfalfa hay pellets, and $0.2 \mathrm{~kg}$ barley grain. The ration was completed with concentrate pellets $\left(0.6 \mathrm{~kg} \cdot \mathrm{d}^{-1}\right)$ offered individually in two equal portions at 9.00 and $16.00 \mathrm{~h}$.

Each group of goats was randomly assigned to one of the two dietary treatments: concentrate pellets without supplement (control; C), and concentrate pellets supplemented with malate and yeast culture (MY). For the MY group, a mixture of sodium and calcium malate (55\%), $S$. cerevisiae culture (15\%) and excipient $(30 \%)\left(\right.$ Gustor XXI ${ }^{\circledR}$, Norel \& Nature S.A., Lliçá de Vall, Barcelona, Spain) was included in the concentrate pellets at a level of $10 \mathrm{~g} \cdot \mathrm{kg}^{-1}$ (Tab. I) and this provided

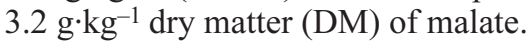

\subsection{Measurements and analysis}

The forage mixture was offered daily at a rate of $130 \%$ of the previous average week intake, and the orts were weighed daily. Daily samples of the forage mixture and the orts were collected and composited 
Table I. Ingredient and chemical composition of the control (C) concentrate and the same concentrate supplemented with the malate-yeast culture mixture (MY) fed to dairy goats.

\begin{tabular}{lcc}
\hline Composition & \multicolumn{2}{c}{ Concentrate } \\
\cline { 2 - 3 } & $\mathrm{C}$ & MY \\
\hline Ingredient (\%) & & \\
Barley & 52.8 & 51.8 \\
Soybean meal 44\% & 30.5 & 30.5 \\
Fish meal & 7.0 & 7.0 \\
Calcium soap $^{1}$ & 3.0 & 3.0 \\
Salt & 3.0 & 3.0 \\
Dicalcium phosphate $_{\text {Premix }}^{2}$ & 3.0 & 3.0 \\
Biomet Zn-10\% $^{3}$ & 0.5 & 0.5 \\
Malate-yeast mixture $^{4}$ & 0.2 & 0.2 \\
Chemical (\% DM) & $\ldots$ & 1.0 \\
Dry matter & & \\
Organic matter & 91.1 & 91.2 \\
Crude protein & 88.9 & 89.1 \\
Crude fiber & 28.4 & 27.1 \\
Malate & 4.5 & 5.2 \\
\hline
\end{tabular}

${ }^{1}$ Magnapac (Norel S.A., Madrid, Spain) composition $\left(\mathrm{g}^{\mathrm{kg}} \mathrm{kg}^{-1}\right)$ : fat, 844; ash, 156; Ca, 90.

${ }^{2}$ Premix Setna ovejas y cabras (Setna, Madrid, Spain) composition per kg: vitamin A, $5000000 \mathrm{IU}$; vitamin $\mathrm{D}_{3}$, 1000000 IU; vitamin E, 5000 mg; Fe, 15 g; Mn, 35 g; I, 1 g; Co, 0.25 g; Zn, 25 g; Se, 0.1 g; Mg, 7.5 g; BHT antioxidant, $2 \mathrm{~g}$.

${ }^{3}$ Biomet $\mathrm{Zn}-10 \%$ (Norel S.A., Madrid, Spain): $\mathrm{ZnSO}_{4}, 30 \%$; methionine, $25 \%$; kaolin, 45\%.

${ }^{4}$ Gustor XXI (Nature S.A., Barcelona, Spain): mixture of sodium and calcium malate, $55 \%$; Saccharomyces cerevisiae culture, $15 \%$; excipient, $30 \%$.

throughout the experimental period for analysis of the chemical composition. The samples were ground through a $1-\mathrm{mm}$ stainless steel screen and were then analyzed for DM, crude protein (Kjeldahl $\mathrm{N} \times$ 6.25), crude fiber, and ash according to AOAC [3] procedures.

The goats' BW were recorded at week 2 and 3 of lactation and then every 4 weeks after milking and prior to feeding. The milk yield of each goat was recorded weekly by using the recording jars in the milking parlor. Milk samples for composition analysis were taken at weeks 2 and 3 of lactation, and then biweekly until the end of the experiment. The samples (approximately $100 \mathrm{~mL}$ ) were preserved with $0.03 \%$ potassium dichromate and were analyzed without homogenization for total solids, fat, protein $(\mathrm{N} \times 6.38)$ and casein using a near infrared spectrophotometer
(Technicon InfraAlyzer-450, Bran+Luebbe SL, Nordersted, Germany) according to Albanell et al. [1].

For malate determination, $0.5 \mathrm{~g}$ of ground feed samples were mixed with $12.5 \mathrm{~mL}$ of deionized water in a glass tube and were boiled in a $100{ }^{\circ} \mathrm{C}$ water bath for $30 \mathrm{~min}$. The samples were then mixed using a glass-stirring rod to release organic acids from the cellular membranes. The slurry was filtered and the tube and the residue were rinsed with $12.5 \mathrm{~mL}$ of deionized water to remove malate residues. The filtrate was collected for the analysis of malate by High-Performance Liquid Chromatography (Waters 600E, Waters 486 UV absorption detector at $214 \mathrm{~nm}, \mathrm{D}-2500$ MerckHitachi integrator, $100-\mu \mathrm{L}$ loop; Waters HPLC system, Waters Corporation, Milford, Massachusetts, USA) at $35^{\circ} \mathrm{C}$ using a Bio-Rad HPX-87H Aminex organic 
column (Bio-Rad Laboratories, Hercules, CA, USA). The samples were eluted from the column with $4 \mathrm{mM} \mathrm{H}_{2} \mathrm{SO}_{4}$ at a flow rate of $0.5 \mathrm{~mL} \cdot \mathrm{min}^{-1}$ and malate was expressed as the anion of malic acid.

\subsection{Statistical analysis}

The PROC MIXED for repeated measurements of SAS (version 6.12) was used for analysis of variance. The statistical model contained the effects of treatment, parity, prolificacy, week as the repeated factor, and the first order interaction of these effects. When the probability of an interaction term was not significant $(P>0.20)$, the interaction term was deleted from the model. Data from weeks 2 and 3 were used as a covariate to correct for the differences in the initial values when necessary. The covariance structure that yielded the largest Schwarz Bayesian criterion was considered to be the most suitable analysis. Differences were declared at a significance level of $P<0.05$.

\section{RESULTS AND DISCUSSION}

The ingredients and chemical composition of the experimental concentrate pellets and the basal diet are presented in Tables I and II, respectively. As shown in Table I, the concentrate fed to the MY group was slightly lower in protein (1.3 percentage units) than the concentrate fed to the $\mathrm{C}$ group probably due to dosing differences of the ingredients in the fabrication process.
Nevertheless, this difference in protein between $\mathrm{C}$ and MY concentrates was not relevant for the total protein supply since goats in the $\mathrm{C}$ group received only $7 \mathrm{~g}$ more of crude protein (approximately 3\% of daily requirements) than goats in the MY group. Moreover, both groups were fed approximately $120 \%$ of protein requirements recommended by INRA [16]. In the present study, alfalfa hay pellets contained less malate $\left(14 \mathrm{~g} \cdot \mathrm{kg}^{-1}\right)$ than the values reported previously [6] for different varieties of fresh alfalfa $\left(30-75 \mathrm{~g} \cdot \mathrm{kg}^{-1}\right)$ suggesting that the haymaking and pelleting processes led to losses in malate. Malate content in the MY concentrate pellets was greater than in $\mathrm{C}$ as a result of the addition of Gustor $\mathrm{XXI}^{\circledR}$ and hence the goats in the MY group received $2 \mathrm{~g}$ more malate per day than the $\mathrm{C}$ goats. The basal diet (forage, alfalfa pellets and barley) provided $8.12 \mathrm{~g} \cdot \mathrm{kg}^{-1} \mathrm{DM}$ of malate. Moreover, the goats in the MY group received $0.9 \mathrm{~g}$ of $S$. cerevisiae daily (S. cerevisiae accounted for $15 \%$ of the malate-yeast mixture).

The initial and final BW did not differ between the treatment groups (Tab. III). However, daily BW gain in the MY group was higher $(P<0.03)$ than in the $\mathrm{C}$ group (39 vs. $19 \mathrm{~g} \cdot \mathrm{d}^{-1}$ for the MY and C groups, respectively), which may indicate a greater energy deposition as body fat in the MY supplemented goats. Mean daily DM intake (Fig. 1; Tab. III) did not differ between the experimental groups and averaged $2.03 \mathrm{~kg} \cdot \mathrm{d}^{-1}$, which is in accordance with the expected intake for goats of similar BW and milk yield $[16,21]$.

Table II. Chemical composition of the ingredients of the basal diet fed to dairy goats.

\begin{tabular}{lccc}
\hline Item $(\%)$ & Barley grain & Alfalfa pellets & Dehydrated maize and alfalfa \\
\hline Dry matter & 89.5 & 91.8 & 92.4 \\
Dry matter basis: & & & \\
$\quad$ Organic matter & 97.6 & 88.7 & 92.8 \\
Crude protein & 10.4 & 15.7 & 10.1 \\
Crude fiber & 5.9 & 25.7 & 31.0 \\
Malate & 0.31 & 1.42 & 0.73 \\
\hline
\end{tabular}


Table III. Performance of Murciano-Granadina dairy goats fed a control (C) concentrate or the same concentrate supplemented with malate-yeast culture mixture (MY).

\begin{tabular}{|c|c|c|c|c|}
\hline \multirow[b]{2}{*}{ Item } & \multicolumn{2}{|c|}{ Treatment } & \multirow[b]{2}{*}{ SEM } & \multirow[b]{2}{*}{ Effect $(P<)$} \\
\hline & $\mathrm{C}$ & MY & & \\
\hline \multicolumn{5}{|l|}{$\mathrm{BW}(\mathrm{kg})$} \\
\hline Initial & 43.4 & 42.4 & 1.37 & 0.412 \\
\hline Final & 45.0 & 45.6 & 1.22 & 0.889 \\
\hline BW change $\left(g \cdot d^{-1}\right)$ & 19 & 39 & 9.0 & 0.028 \\
\hline DMI $\left(\mathrm{kg} \cdot \mathrm{d}^{-1}\right)$ & 2.04 & 2.02 & 0.012 & 0.355 \\
\hline Milk yield $\left(\mathrm{L} \cdot \mathrm{d}^{-1}\right)$ & 2.09 & 2.08 & 0.023 & 0.458 \\
\hline Persistency of milk production ${ }^{1}$ & 96.5 & 98.0 & 2.17 & 0.747 \\
\hline \multicolumn{5}{|l|}{ Milk composition $(\%)$} \\
\hline Total solids & 13.6 & 13.2 & 0.24 & 0.359 \\
\hline Fat & 5.17 & 4.85 & 0.192 & 0.328 \\
\hline Protein & 3.70 & 3.63 & 0.123 & 0.808 \\
\hline Casein & 2.57 & 2.51 & 0.112 & 0.776 \\
\hline
\end{tabular}

${ }^{1}$ Calculated as treatment/pretreatment $\times 100$.

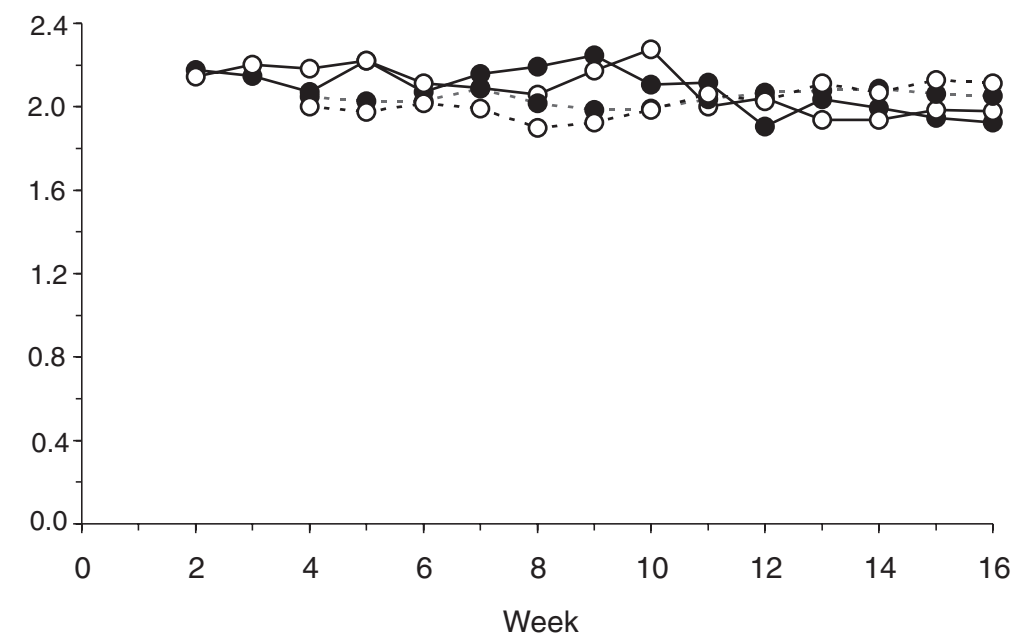

Figure 1. Milk yield $\left(\mathrm{L} \cdot \mathrm{d}^{-1}, \longrightarrow ; \mathrm{SEM}=0.02\right)$ and dry matter intake $\left(\mathrm{kg} \cdot \mathrm{d}^{-1},---; \mathrm{SEM}=0.01\right)$ of Murciano-Granadina dairy goats fed a $\operatorname{control}(\bullet)$ concentrate or the same concentrate supplemented (○) with a malate and yeast mixture. 


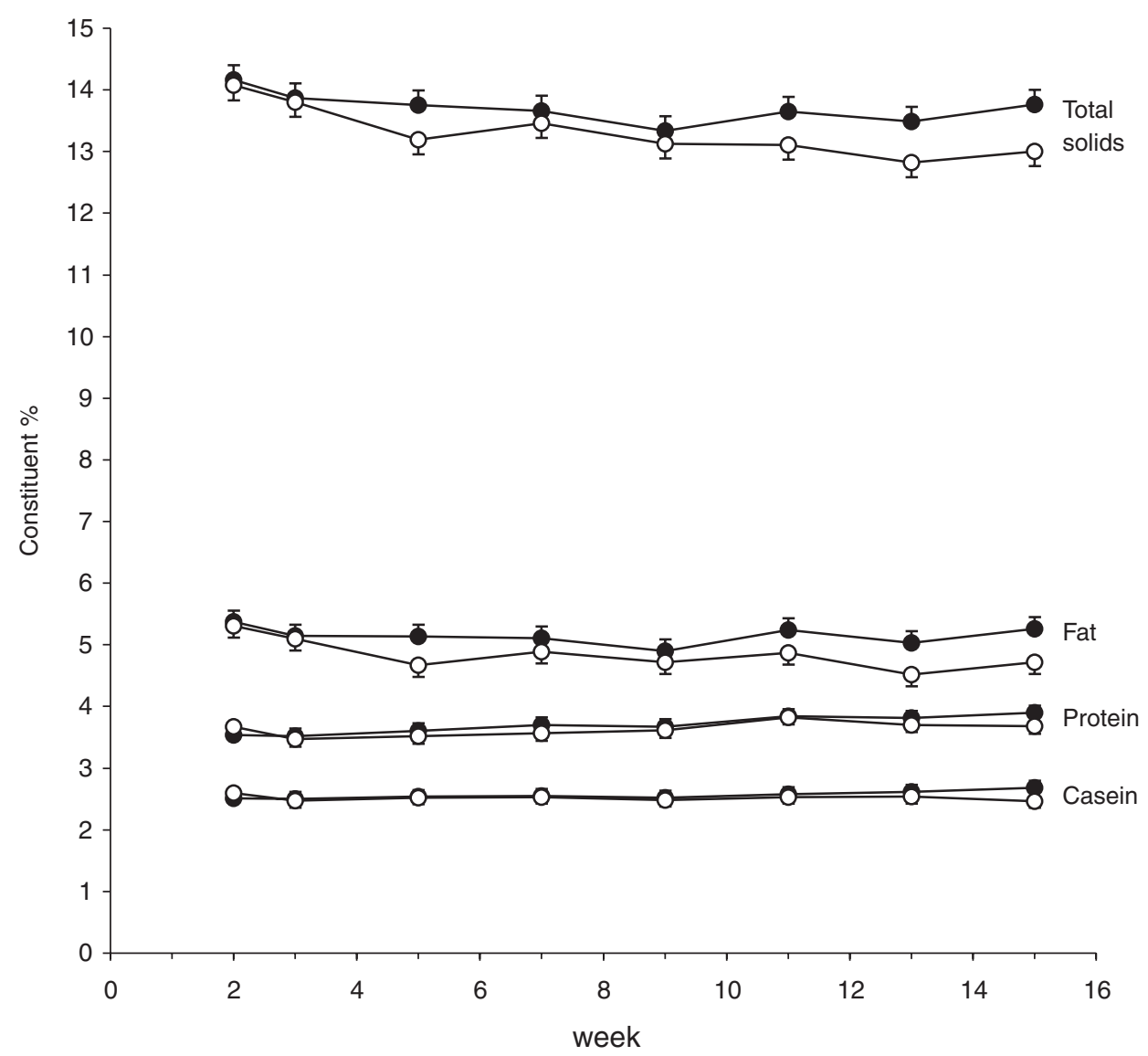

Figure 2. Milk composition of Murciano-Granadina dairy goats fed a control (•) concentrate or the same concentrate supplemented with malate and yeast mixture $(\circ)$.

Supplementation with the mixture of malate and yeast culture did not affect milk yield $\left(2.09 \mathrm{~L} \cdot \mathrm{d}^{-1}\right)$ or the persistency of milk production $(97 \%)$ during the experimental period of 12 weeks. The percentages of total milk solids, milk fat, milk protein and casein were also not affected by the treatments (Fig. 2; Tab. III) and averaged $13.43 \%, 5.01 \%, 3.67 \%$, and $2.54 \%$, respectively. The values of milk yield and milk constituents were slightly higher than those reported in the same breed $[19,21]$.

The non significant effects of malate supplementation in our results agreed with those previously reported in dairy cows fed malic acid $[12,14]$. In contrast, increases in milk yield [24] and in lactation persistency [14] have been reported in malic acid supplemented dairy cows.

In our study, the inclusion of yeast in the diet supplement showed no positive effects either. Nevertheless, the results on the use of yeasts in dairy goats were contradictory. So, while Hadjipanayiotou et al. [13] reported no effects on intake, BW, milk yield or milk composition, Giger-Reverdin et al. [11] observed a significant increase in fat corrected milk yield and fat content in dairy 
goats. Similar contradictory results in yeast supplementation were observed in dairy cows as a consequence of the differences in various factors such as the type of forage fed, feeding strategy, forage to concentrate ratio and stage of lactation $[9,20,23,25]$.

Although no measurements of yeast activity were taken in our experiment after concentrate pelleting, the metabolic activity of yeast should not be affected until $70{ }^{\circ} \mathrm{C}[15]$. Thus, under our conditions of pelleting $\left(60-70{ }^{\circ} \mathrm{C}\right)$ and storage (4 months, $15-20^{\circ} \mathrm{C}$ ), yeast in the present study should be metabolically active after its inclusion in the concentrate and during the experimental period.

Most probably, the lack of a positive effect of malate supplementation in our study was related to the amount of alfalfa included in the diet. In our experiment, the $\mathrm{C}$ group consumed an average $12.3 \mathrm{~g}$ of malate daily. Considering that the average ruminal volume was $7 \mathrm{~L}$ for MurcianoGranadina goats, as calculated from the range of the values reported by Silanikove et al. [22], the intraruminal concentration of malate was $1.75 \mathrm{~g} \cdot \mathrm{L}^{-1}$ or $13.01 \mathrm{mM}$ (molecular mass of malate is 134.1) for the $\mathrm{C}$ goats. Concentrations of malate between 0.03 and $10 \mathrm{mM}$ increased the uptake of lactate by $S$. ruminantium in a dose-response fashion [18]. Therefore, the C diet provided adequate concentrations of malate to stimulate lactate utilization by $S$. ruminantium.

The beneficial effect of malate and yeast may be more important in grain-based diets for fattening ruminants [18]. Gain efficiency was improved in lambs fed high concentrate diets and supplemented with the same product used in this experiment [4]. Since goat diets in our experiment received a moderate percentage of concentrates, the buffering capacity and cellulolytic activity in the rumen were supposed to be sufficient to maintain a good ruminal function, which negated any effects on milk yield and com- position when malate and yeast mixture was supplemented.

\section{CONCLUSIONS}

The supplementation of a mixture of malate and yeast to dairy goats that receive a high proportion of alfalfa in their diets, has no beneficial effects on lactation performances. More studies under different feeding conditions are necessary to clarify the effects of malate and yeast culture supplementation to the diets of dairy goats.

\section{ACKNOWLEDGMENT}

The authors are grateful to Juan Mesiá and Mónica Puyalto (Norel \& Nature S.A., Spain) for supporting this research. The authors are also grateful to Ramón Costa and the team of the S1GCE (Servei de Granges i Camps Experimentals) of the UAB for the care of the animals and to Nic Aldam for reviewing the manuscript.

\section{REFERENCES}

[1] Albanell E., Cáceres P., Caja G., Molina E., Gargouri A., Determination of fat, protein, and total solids in ovine milk by near-infrared spectroscopy, J. AOAC 82 (1999) 753-758.

[2] Asanuma N., Iwamoto N., Tsuneo H., Effect of the addition of fumarate on methane production by ruminal microorganisms in vitro, J. Dairy Sci. 82 (1999) 780-787.

[3] Association of Official Analytical Chemists, Official Methods of Analysis, Vol. I, 16th ed., AOAC, Arlington, VA, 1995.

[4] Caja G., Garín D., Mesiá J., Stimulating rumen fermentation: organic acids salt as growth promoters, Feed Intr. 21 (2000) 23-25.

[5] Callaway T.R., Martin S.A., Effects of organic acid and monensin treatment on in vitro mixed ruminal microorganism fermentation of cracked corn, J. Anim. Sci. 74 (1996) 1982-1989.

[6] Callaway T.R., Martin S.A., Wampler J.L., Hill N.S., Hill G.M., Malate content of forage varieties commonly fed to cattle, J. Dairy Sci. 80 (1997) 1651-1655. 
[7] Caldwell D.R., Bryant M.P., Medium without rumen fluid for non-selective enumeration and isolation of rumen bacteria, Appl. Microbiol. 14 (1966) 794-800.

[8] Carro M.D., Lopez S., Valdés C., Ovejero F.J., Effect of DL-malate on mixed ruminal microorganism fermentation using the rumen simulation technique (RUSITEC), Anim. Feed Sci. Technol. 79 (1999) 279-288.

[9] Dann H.M., Drackley J.K., McCoy G.C., Hutjens M.F., Garrett J.E., Effects of yeast culture (Saccharomyces cerevisiae) on prepartum intake and postpartum intake and milk production of Jersey cows, J. Dairy Sci. 83 (2000) 123-127.

[10] European Commission (EC-DGXI), Options to reduce methane emissions. Final report, AEAT-3773: issue 3, 1998.

[11] Giger-Reverdin S., Bezault N., Sauvant D., Bertin G., Effects of a probiotic yeast in lactating ruminants: interaction with dietary nitrogen level, Anim. Feed Sci. Technol. 63 (1996) 149-162.

[12] Hackett H., Kreider D.L., Hardesty D., Hornsby P., Effects of malic acid supplementation in postpartum cows, J. Anim. Sci. 73 (Suppl. 1) (1995) 254.

[13] Hadjipanayiotou M., Antoniou I., Photiou A., Effects of the inclusion of yeast culture on the performance of dairy ewes and goats and the degradation of feedstuffs, Livest. Prod. Sci. 48 (1997) 129-134.

[14] Kung L. Jr., Huber J.T., Krummrey J.D., Allison L., Cook R.M., Influence of adding malic acid to dairy cattle rations on milk production, rumen volatile acids, digestibility, and nitrogen utilization, J. Dairy Sci. 65 (1982) 1170-1174.

[15] Moore E., Assessing the viability of pelleted direct-fed microbials and specifically yeast cultures in feed, in: Lyons T.P. (Ed.), Alltech's 7th Annual European Lecture Tour, 1993, p. 80.

[16] Morand-Fehr P., Sauvant D., Goats, in: Jarrige R. (Ed.), Ruminant nutrition: recommended allow- ances and feed tables, INRA, John Libbey Eurotext, Paris, 1989, pp. 169-180.

[17] Newbold C.J., Wallace R.J., McIntosh F.M., Mode of action of the yeast Saccharomyces cerevisiae as a feed additive for ruminants, Brit. J. Nutr. 76 (1996) 249-261.

[18] Nisbet D.J., Martin S.A., Effect of a Saccharomyces cerevisiae culture on lactate utilization by the ruminal bacterium Selenomonas ruminantium, J. Anim. Sci. 69 (1991) 4628-4633.

[19] Peris S., Caja G., Such X., Casals R., Ferret A., Torre C., Influence of kid rearing systems on milk composition and yield of MurcianoGranadina dairy goats, J. Dairy Sci. 80 (1997) 3249-3255.

[20] Piva G., Belladonna S., Fusconi G., Sicbaldi F., Effects of yeast on dairy cow performance, ruminal fermentation, blood components, and milk manufacturing properties, J. Dairy Sci. 76 (1993) 2717-2722

[21] Salama A.A.K., Caja G., Albanell E., Such X., Casals R., Plaixats J., Effects of dietary supplement of zinc methionine on milk production, udder health and zinc metabolism in dairy goats, $\mathrm{J}$. Dairy Res. 69 (2002) in press.

[22] Silanikove N., Tagari H., Shkolnik A., Comparison of rate of passage, fermentation rate and efficiency of digestion of high fiber diet in desert Bedouin goats as compared to Swiss Saanen goats, Small Ruminant Res. 12 (1993) 45-60.

[23] Soder K.J., Holden L.A., Dry matter intake and milk yield and composition of cows fed yeast prepartum and postpartum, J. Dairy Sci. 82 (1999) 605-610.

[24] Stallcup O.T., Influence of addition of DL-malic acid to diets of lactating dairy cows, J. Dairy Sci. 62 (Suppl. 1) (1979) 225.

[25] Wohlt J.E., Finkelstein A.D., Chung C.H., Yeast culture to improve intake, nutrient digestibility, and performance by dairy cattle during early lactation, J. Dairy Sci. 74 (1991) 1395-1400. 
